\title{
معوقات استخدام المعامل الافتراضية لدى معلمي العلوم الطبيعية بالمرحلة الثانوية
}

\section{ماجر بن عبر الله الطويرقي}

هدفت الدراسة إلى التعرف على معوقات استخدام الدعامل الافتراضية الدتعلقة بالدعلم والمتعلم ، و الادارة الددرسية وبمقررات العلوم، وبيقتنيات الحاسب والتجهيزات العدرسية ، من وجهة نظر معلمي العي

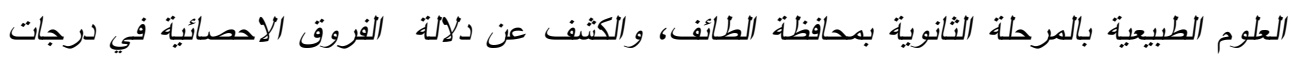

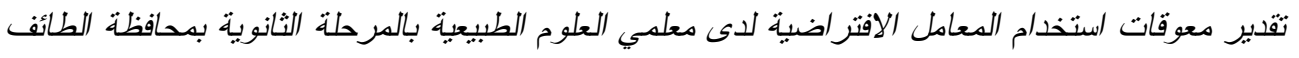

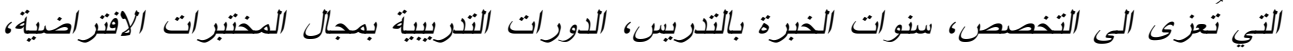
وجود غرفة مصادر مستقلة بالمدرسة.

اتبعت الدراسة الدنهج الوصفي المسحي. وتمثلت أداة الدراسة في استبانة مكونة من جزأين رئيسين؛ الجزء الأول: الدعلومات العامة، والجزء الثاني: مكون من خمس محاور؛ تشعل الدعوقات

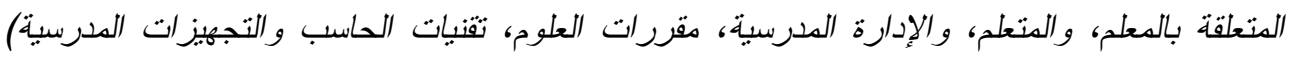

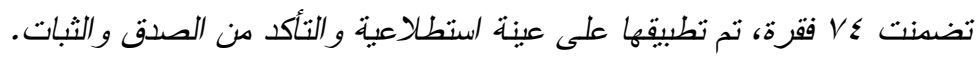

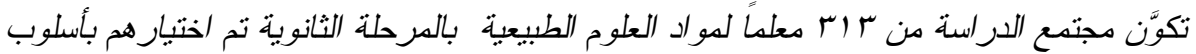

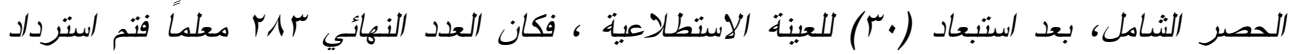

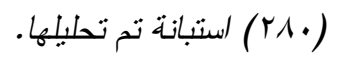

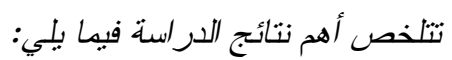

- إن المتوسط الكلي للرجة وجود الدعوقات في استخدام الدعامل الافتراضية لدى معلدي العلوم

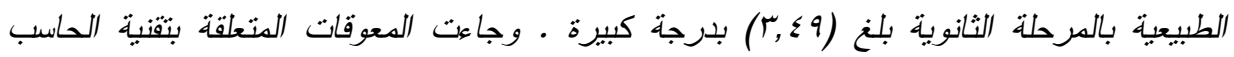

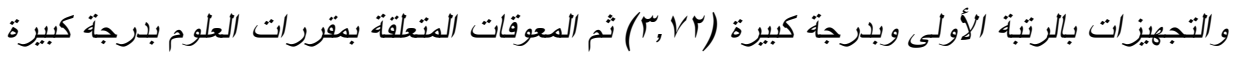

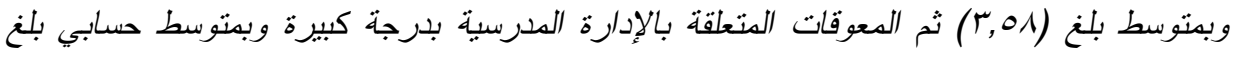

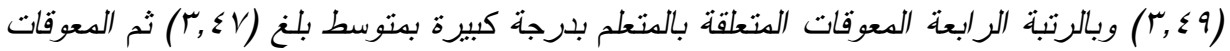

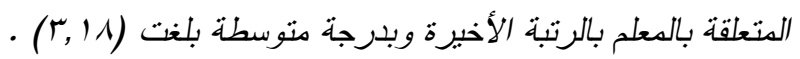

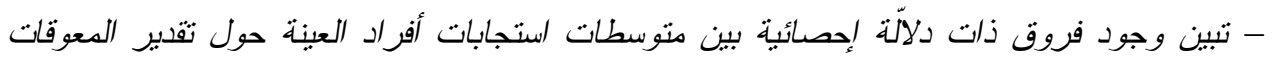

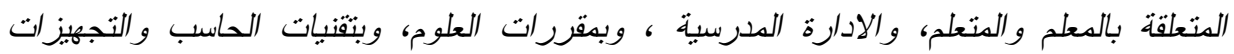

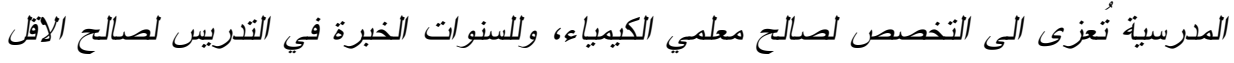
خبرة، وفي الدورات التدريبية لصالح غير حاصلين على دورات تدربيية بدجال الدختبرات 
الافتراضية، وكذلك تبين وجود فروق لصالح المعلمين بالددارس الثانوية التي لا يتوافر فيها غرفة مصادر مستقلة بالمدرسة. - ضرورة الععل على معالجة الدعوقات التي كثفت عنها الدراسة، وتوفبر البرمجيات الحاسوبية الكتعلقة بقررات العلوم الطبيعية وخصوصاً مقرر الكيمياء ، وضرورة العمل على تدريب الدعلدين

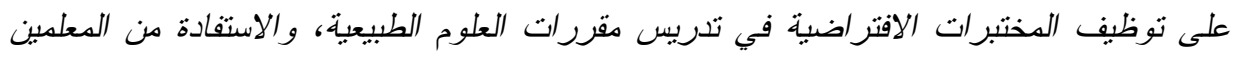
أصحاب الخبرات في التنديب وتوظيف المختبرات الإفتراضية.

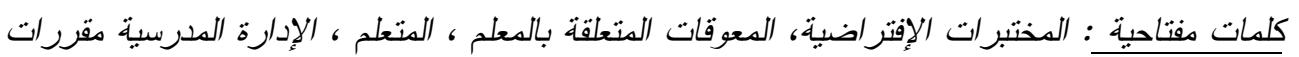

$$
\text { العلوم التجهيزات و البرمجيات الحاسوبية. }
$$

ومتسار عة حيث شهدت الـسنوات الأخيــرة

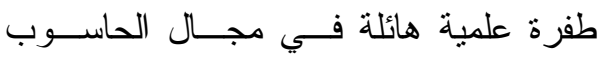

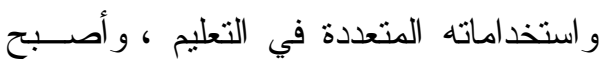

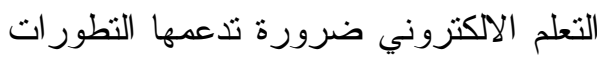

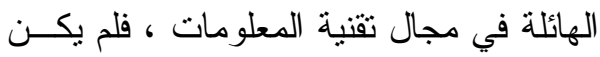

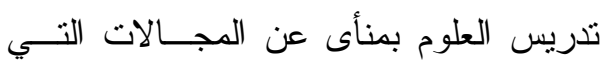

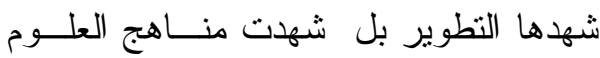

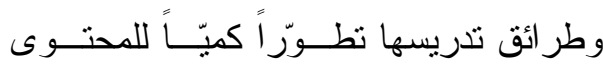

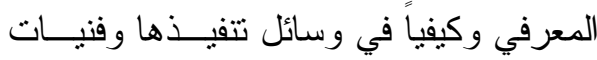
تدريسها، و ألقت المسـستحدثات الالكترونيـــة

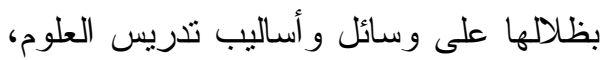
وتم توظيف الحاسوب و التقنيات الحديثة بما يعرف بالمعامل الافتر اضية كإحدى تطبيقات المستحدثات التكنولوجية في العملية التعليمية و التزبوية، وتوظيفها لتحسين عمليتي الــتعلم و التعليم.

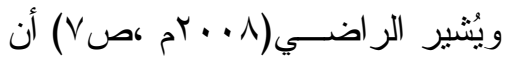
استخدام المعامل الافتر اضية وسيلة تعليميــة

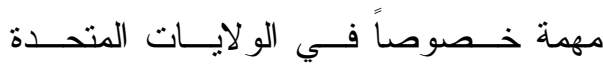

يعتبر المختبر المدرسي من العناصر الضرورية التي يجب نو افر ها بالمدرسة أيــاً كان حجمها ومكانها حيــث إن المختبــــرات المدرسية تمثنّل القلب النابض فــي تــدريس

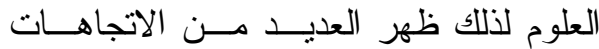
و الاستر اتيجيات الحديثة بمجال تدريس العلوم

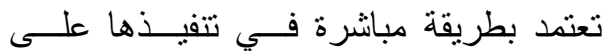
التجريب العملي و التزبية العلمية حيث وضح بند

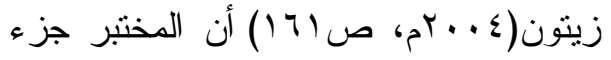
لا يتجز أ في التربية العلمية وتدريس العلــوم

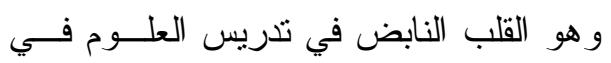

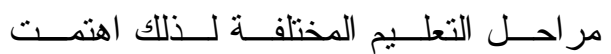

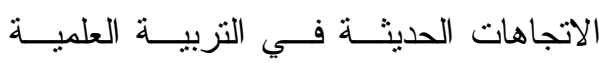

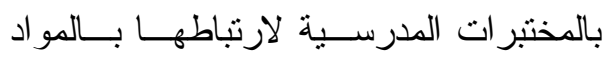

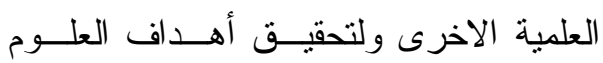

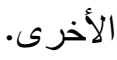
ويتصف العصر الحالي بعصر التقنية لأن العالم يعيش ثــورة تكنولوجيــة هائلـــة 


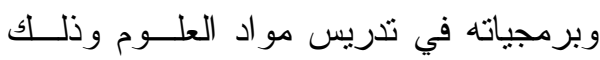

لاستخدامها في معالجة كم هائل من المشاكل فئل فئل التي تو اجه تدريس هذه المو اد .

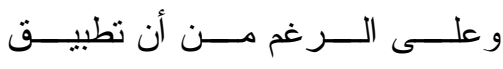

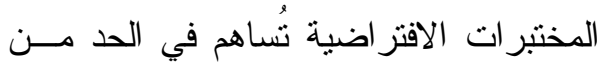
تلك الصعوبات ومعوقات تدريس العلوم، إلا أنها هي كذللك تو اجه العديد من الــصعوبات و المعوقات وبالرغم من الإمكانــات الهائلــــة التي قدّمتها وز ارة التربية و التعلــيم لإنجــــاح مشاريع التعليم الالكتروني ومنها المختبرات

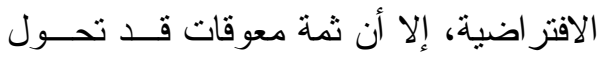

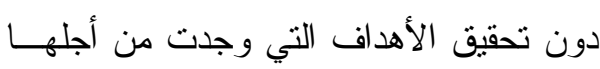

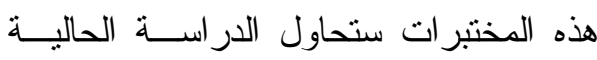
الكثف عنها.

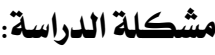

يعيش العــالم اليــوم ثــورة علميـــة

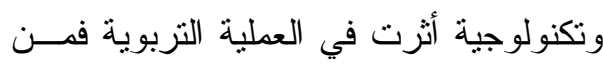

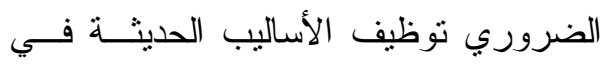
تدريس العلوم، ولقد أثنارت در اسات محليـــة عديدة إلى أهمية تقنية المعامل الافتر اضــية ولية في اكساب المتعلمين مهار ات علمية عاليـــة

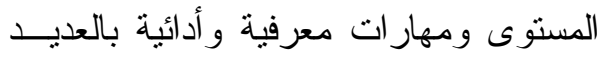
من مواد مقررات العلــوم بـــالتعليم العــام

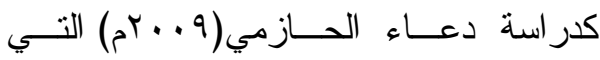
أثنارت إلى أن المعمل الافتر اضي يُمنل قمة ما أنتجته التقنية الحديثة في مجــال تطــــير طرق تدريس العلوم لجميع مر احله

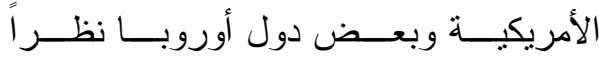

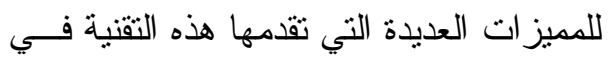

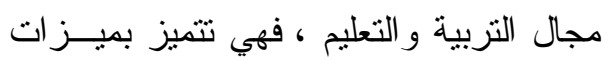
عديدة تدعو إلى التأكيد على أهميتها وتبنيهــا

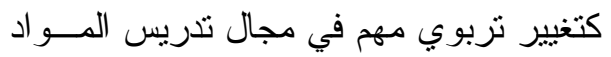

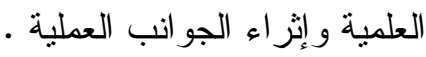
حيث تعتبـــر المعامـلـ الافتراضـــية

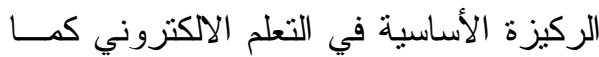

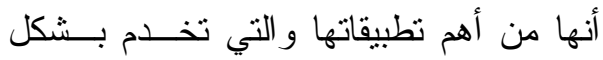

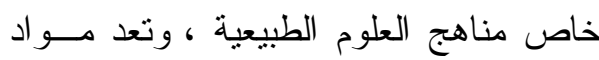
العلوم الطبيعية من أهم المو اد التي تحتاج في لهني

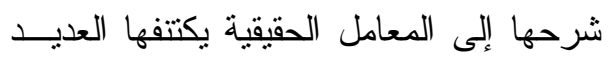
من المعوقات التي تتمنل في كتهـرة أعـــداد المتعلمين وعدم توفر الأجهزة و المواد الكافية لممارسة التجارب العملية بـشكل مناســب.

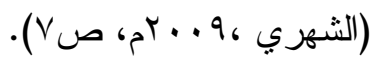

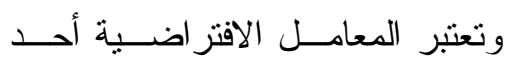
مستحدثات التكنولوجيا الحديثة وتعتبر امتداداً لتطور أنظمة التعليم الالكتروني، وتعد حــالًا للمشكلات المتعددة التي تواجه النظم التعليمية

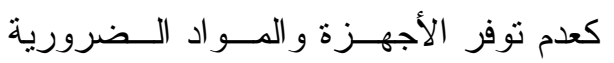

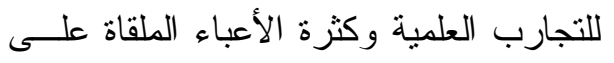

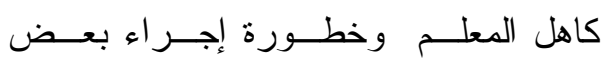

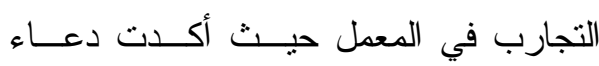

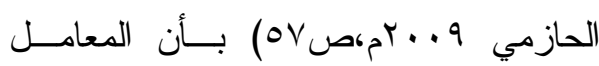

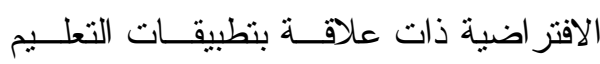

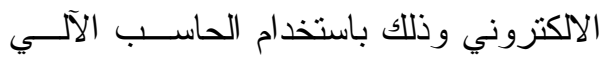


r)ما معوقات استخدام المعامل الافتز اضية

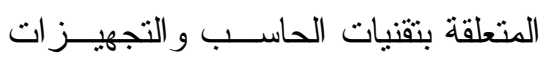

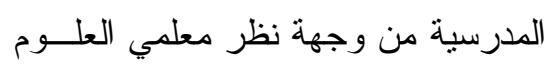

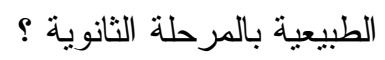

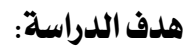
هدفت الدر اسة إلى ما يلي: 1. التعرف على معوقات استخدام المعامل

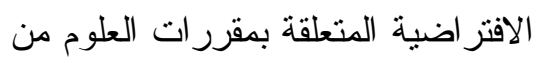
وجهة نظر معلمــي العلــوم الطبيعيــة بالمرحلة الثانوية. r. التعرف على معوقات استخدام المعامل

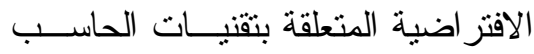
و التجهيزات المدرسية من وجهة نظــــر

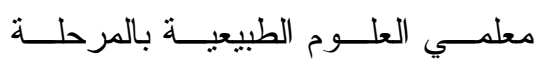
الثانوية.

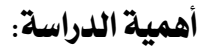

تكمن أهمية الدراسة في النقاط الثالية: ا ـ يشكل البحث إضافة نوعيــة للمعرفـــة التز اكمية لموضوع المعامل الافتر اضية

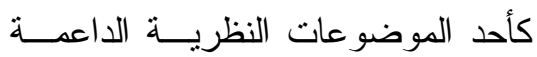

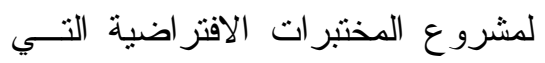

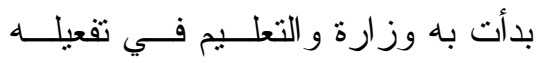

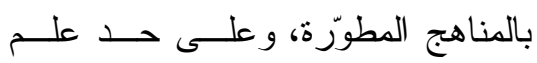
الباحث هنالك قلة من الدر اســات التـي وعي

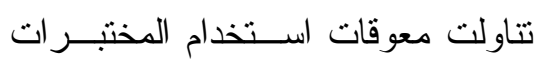
الافتر اضية في تدريس مقررات العلوم الطبيعية بمدارس المرحلة الثانوية.
ومن خلال عمل الباحث في تــدريس مادة العلوم و عملهِ كمعلم تبين له تدني قناعة

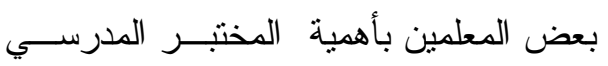
الافتز اضي، وتدني إلمام بعض معلمي العلوم

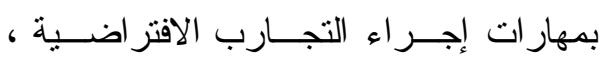

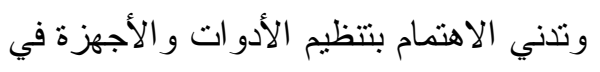

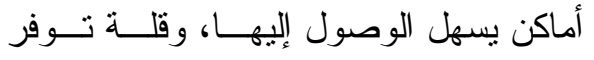

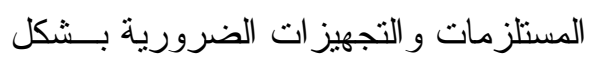
كافٍ، وشيوع طرق التدريس التي لا تتطلب

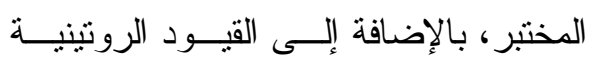

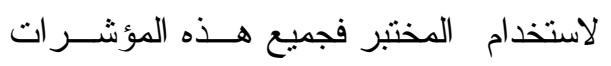

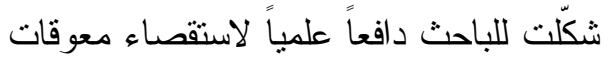

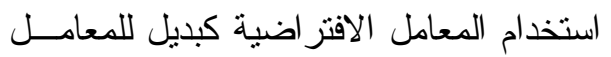
التقليدية وخاصّة في ظل تطور استر اتيجيات التدريس الحديث . وبناءً على ما سبق يمكن التعبير عن مشكلة الدر اسة في السؤال الرئيس التالي : "ما معوقات استخدام المعامل الافتر اضــية

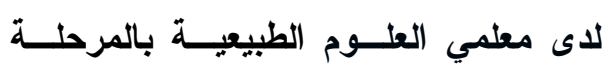

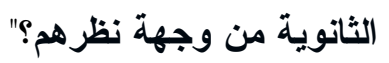

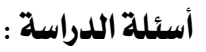
وللإجابة عن هذا السؤال فقد تم تقريعه إلـى السى

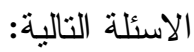
()ما معوقات استخدام المعامل الافتز اضية

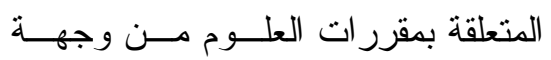
نظر معلمي العلوم الطبيعيــة بالمرحلــــة

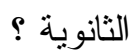




\section{مصطلحات الدراسة:}

ا - المعمل المدرسي laboratory (lab) school

عرفه كل من شاهين وحطاب(1... rم،

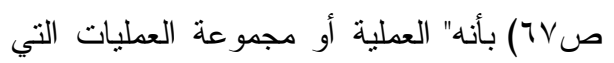

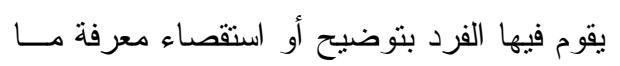
عن طريق العمل، وقد يقوم بعمله هذا في حدود

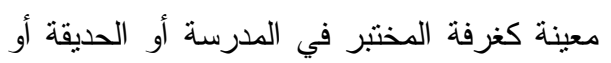
الغابة أو البحر أو أي مكان آخر.

ويقصد بالمعمل المدرسي إجرائيـاً:

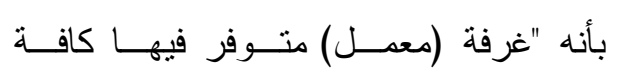

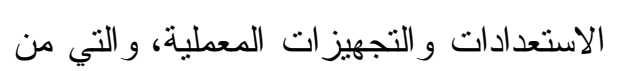

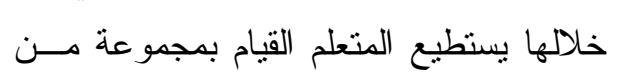

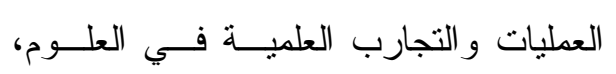
ويطلق عليها مختبر أو معمل العلوم . r - المعمل الافتراضي Virtual Lab تعرف المعامل الافتز اضية بأنها بيئـة

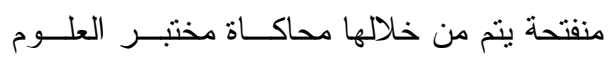

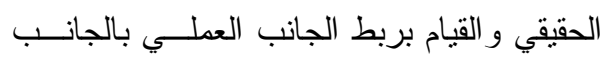
النظري، ويتم من خلاله تدريس مهار ات التفكير، ويكون لاى المتعمين مطلق الحرية في اتخــاذ القرار ات بأنفسهم دون أن يكون لذلك أي آنـار

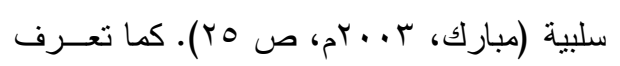

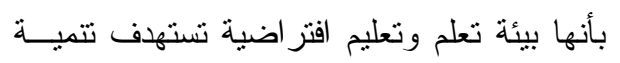
مهار ات العمل المخبري لدى المتعلمين وتقع هذه

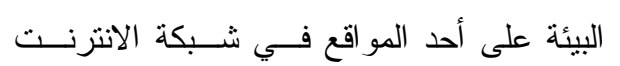

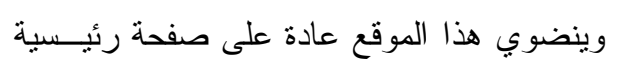
ولها عدد من الروابط أو الأيقونــات (الأدوات) r ـ تزود نتــائج البحـــث معلمـــي العلــوم

الطبيعية بالمرحلة الثانوية و المــشرفين

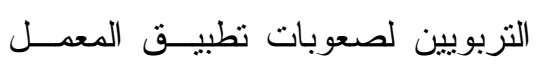

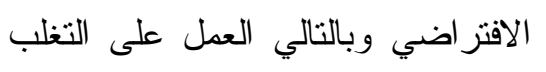

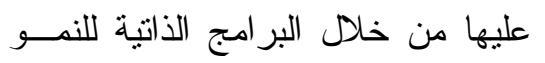

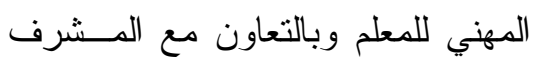
التربوي وأمناء مر اكز مصدادر الــتعلم في المدارس. حدود الدراسـة: تتمنّل حدود الدر اسة فيما يلي :

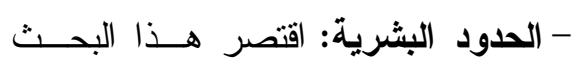
علــــى معلمــــي العلــــوم الطبيعيـــــة

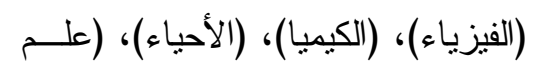

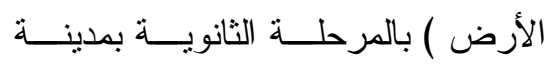
الطائف . الأرص - العدود المكانية : اقتصر هــذا البحــث على المدارس الحكومية الثانوية للبنـين بمدينة الطائف.

- الحدود الزمانية : طُبق هذا البحث فـي

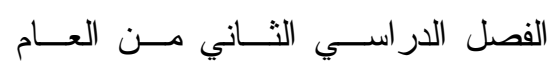

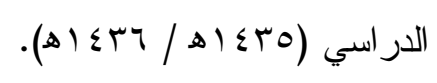
- الحدود الموضــوعية : ركــز البحـــث

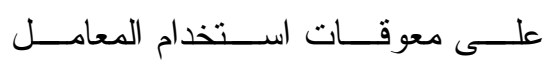
الافتر اضية المتعلقة ومقرر ات العلــوم،

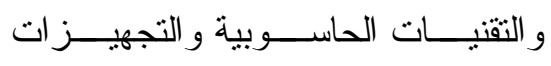
المدرسية 
يؤدي إلى محاولة الإبداع و الاستكثشاف مسـن

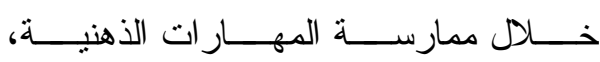
كالملاحظة، و التصنيف، و القياس، و التفسير،

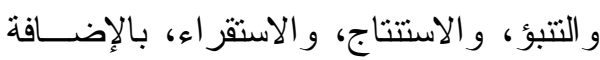

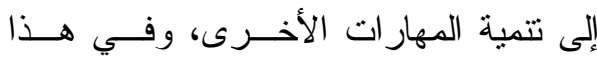
المبحث تم اســتعر اض الموضـــوعات ذات الصلة بالمعامل الافتز اضية من حيث مفهوم المعمل المدرسي بشكل عام ، ثم الانتقال إلى الى المعمل الافتر اضــي مــن حيـــث المفهـــوم

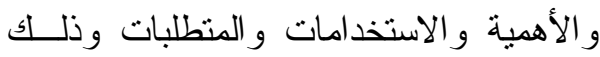
على النحو التالي : أولاً: المعمل المدرسي: اختلف الباحثون في تعريفهم للمعدـل المدرسي باختلاف نظرتهم للمكان الذي يــتم فيه التجريب حيث يذكر المنتشري (V . . بم، ص 1 ) أن سبب الاختلاف هذا يعــود إلـىى :النظرة التقليدية للمعمل باعتباره المكــان الملحق بالمدرسة و الذي ينحــصر فيـــه دور المختبر على ما يجري داخل غرفة المختبـر

$$
\text { من تجارب و عروض. }
$$

ويرى الباحــث أن أهميـــة المعدــل

المدرسي لا تقل أهمية عن اســتخدام تقنيــة

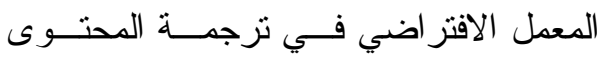
المعرفي بالعلوم إلى و اقع عملي ومــدروس

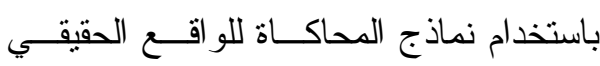
بالتطبيق على التجــارب الافتز اضــية فــي تذريس العلوم، إذ يمكن تحقيق الفو ائد العملية
المتعلقة بالأنشطة المختبرية و إنجاز اتها وتقويمها.

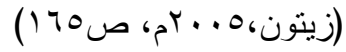

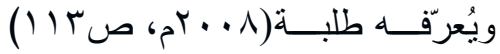

بأنها وسط تفاعلي لإنشاء و إجراء تجــارب عن طريق المحاكاة وهذا الوسط الرســـومي يتكون من بر امج لمحاكاة التجارب تختلــــ

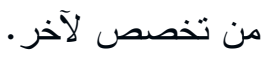

ويقصد بالمعمل الافتر اضي إجرائياً:

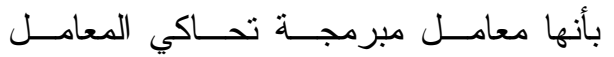
الحقيقية، ومن خلالها يــتمكن المــتعلم مــن إجراء التجارب المعملية عن بعد باســتخدام مواقع على شبكة الانتزنـــت أو برمجيــات الكترونية مُعدّه مُسبقاً . الإطار النظري والدراسات السابقة يأتي هذا الفصل من البحث بوصــفه يمنّ مر اجعة للأدب التزبوي السابق ويتكون من إطار نظري حوى مبحث نتاول المعامل الافتر اضية .كما يتضمّن هذا الفصل مر اجعة جملة من الدر استات السّابقة منهــــا در اســـات عربية ، ودر اسات أجنبية المبحث: المعامل الافتر اضبة وتدريس العلوم يعتبر المعمل المدرسي بـشكل عــام سو اء التقليدي أو الافتز اضـي من المرافــق المهمة و الضرورية فـي المدرســـة و الــذي اهـي يهدف إلى توضيح المفاهيم العلمية الموجودة في مادة العلوم، وترجمة النظريات و القوانين

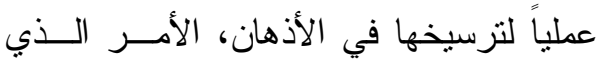


مميزات المعامل الافتراضية :

ا ـ تقليل وقت التعلم الذي يقضيه المتعلمون

$$
\text { في المعمل التقليدي. }
$$

r. إجر اء تجارب يصعب إجر اؤهــا فــي المختبر التقليدي كونها خطرة أو مكلفة

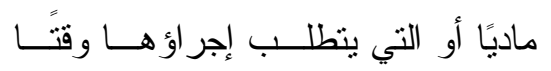

$$
\text { طويلاً في المعدل التقليدي. }
$$

متطلبات التقتية والتجهيزات المدرسية لاستخدام المعامل الافتراضية:

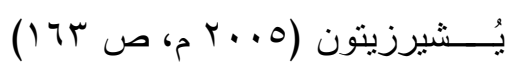

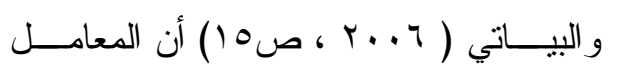
الافتر اضية هي الركيزة الأساسية في التعليم الالكتروني في المجال العملي و النطبيقي فهي

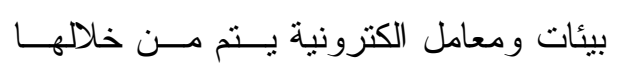

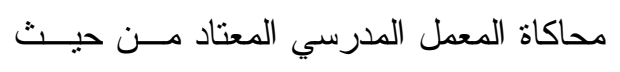

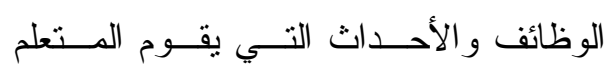
بممارسة الأنشطة المعملية الني تحدث فـي لالتي

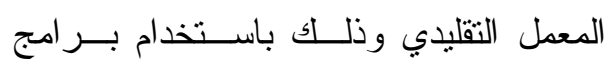
الكترونية مختلفة نجدها على أقر اص مدمجة بادية أو من خلا موقع متاح في أي زمان ومكان على شبكة الإنترنت.

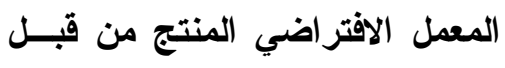

شركة كروكودايـلـل كليبـز (Crocodile) Clips

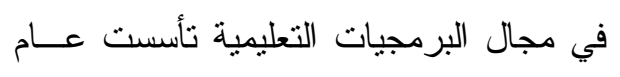
ع 99 ام، و هذه التقنيات مستخدمة في أكثر

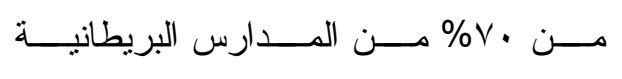

للمختبر ات الحقيقية بالنسبة للمنعلم من خلال تطبيقات المعامل الافتر اضية. مفهوم المعمل الافتر اضي :

يعتبر التوجه نحـــو اســتخدام تقنيــة

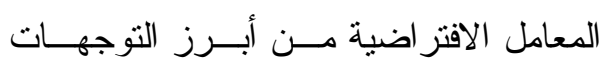
المستحدثة في التعليم. استخدامات المعامل الافتر اضية:

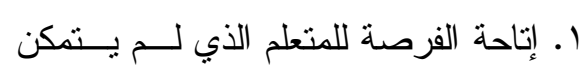

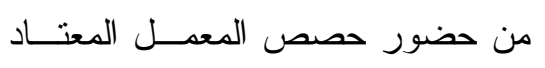

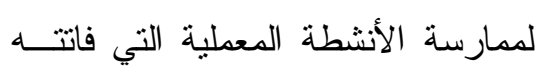
من خلال المعمل الافتز اضي.

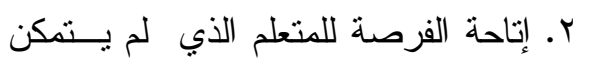

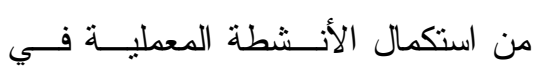

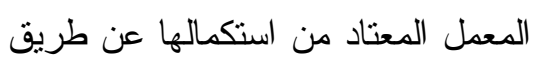
المعمل الافتز اضي.

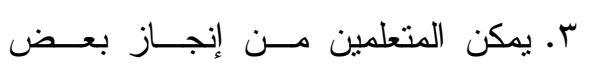
التكليفات المعملية في البيت.

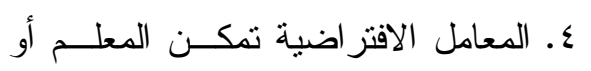

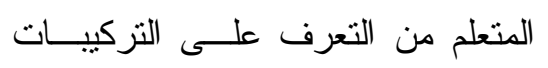
الصغيرة جدًا كالتركيب الذري وحركة الصني

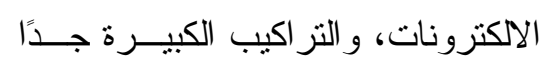
كحركة الأفلاك و الأجر ام السماوية.

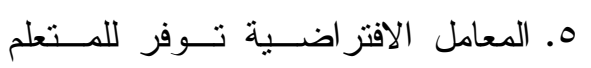

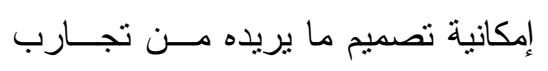

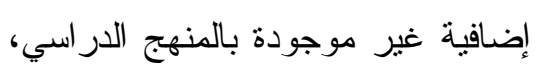
بحيث يكون لكل طالب مكتبة تجـارب خاصة به ومن تصميمه الخاص. 
ونظر الأهمية المعامل الافتر اضــية

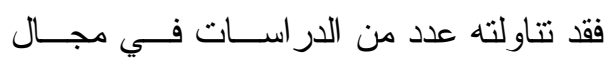

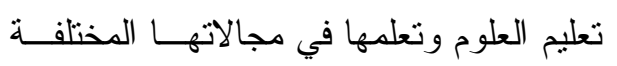
منها :

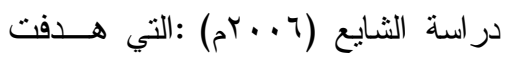

إلى الكثف عن و اقع استخدام مختبر ات العلــوم

المحوسبة في المرحلة الثانوية و اتجاهات معلمي

العلوم و المتعلمين نحو ها وشارك في هذه الدر لسة

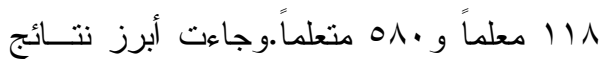

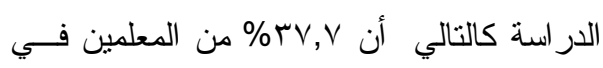

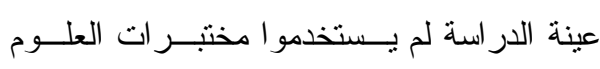

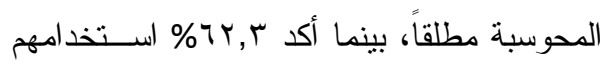

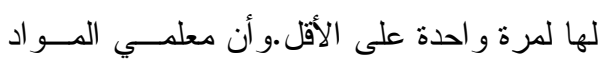

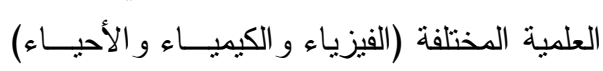
متقاربين إلى حد كبير في مدى استخدامهم لهـا و أكدت الدر اسة على وجود اتجاهات إيجابية لدى

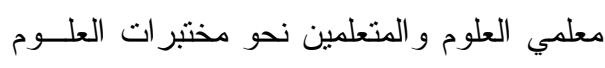
المحوسبة بشكل عام، وكان أكثر هذه الاتجاهات

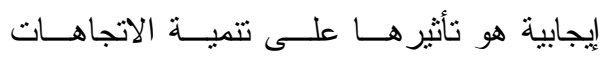

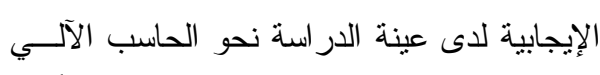

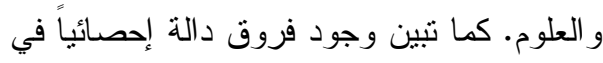

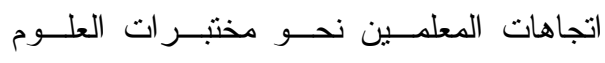
المحوسبة في محور التجهيز و الاستخدام ومحور

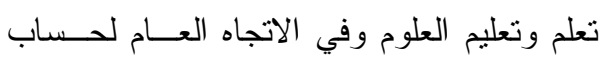

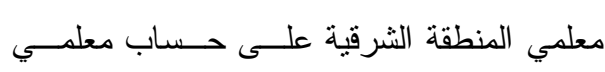
منطقة عسيرو عدم وجود فروق بـين اتجاهــات

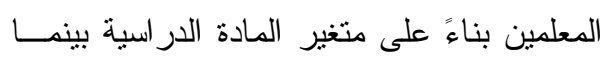

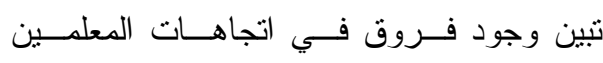

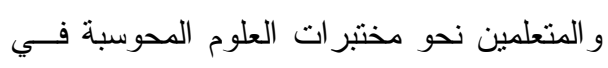

وكذلك مستخدمة في أكثرمن • ج دولة حسول

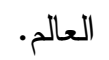
ولقد قامت هذه الثركة بإنتاج معامل

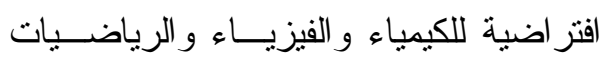

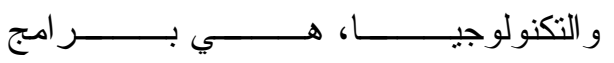

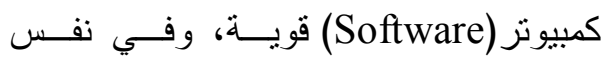

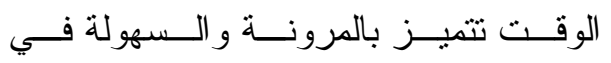

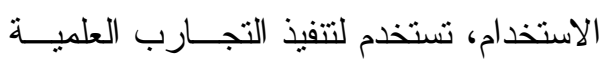

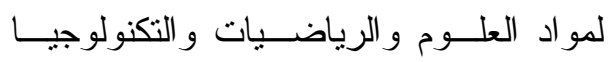
للمر احـلـ الدراســـية المختلفـــة (الابتدائيـــة

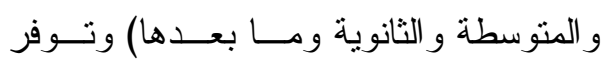

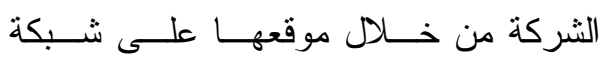

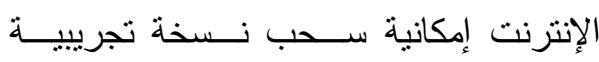

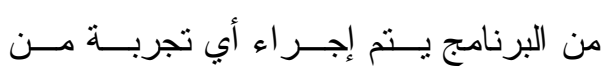

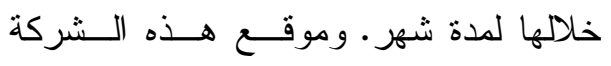
هو : يتتاول الباحث في هذا الجـزءء مــن مر اجعته الأدب التربوي الــسّابق مطالعــة

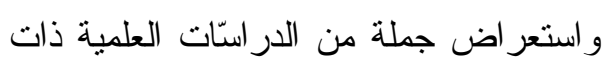

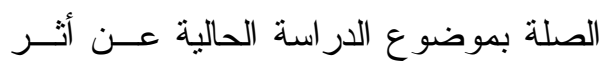
استخدام المعامل الافتر اضية. وقد تم تقسيم هــذه الدر اســات إلـى

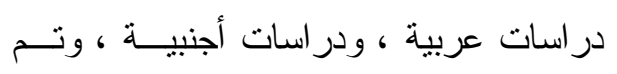
عرض در اسات كل قسم في سياق تــاريخي

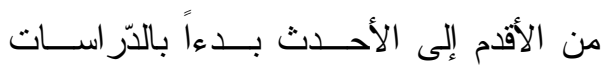
العربية - من الت 
الاختبار التحصيل بجميع المستويات لــصالح

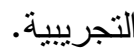

وفي مجال الأحيــاء كانـــت در اســـة

الثهري(9 + . r م) ؛حيث هدفت إلى استقصاء

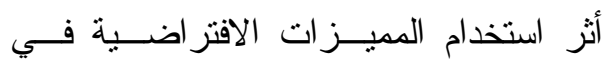

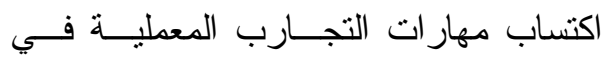

مقرر الأحياء لمتعلمين الصف الثالث الثانوي

بمدينة جدة واستخدم الباحث المـــهـ شـــبه

التجريبي وتم اختيار العينــة مــن مجتمـــع

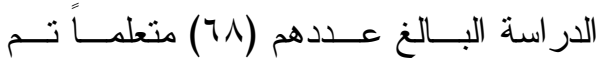

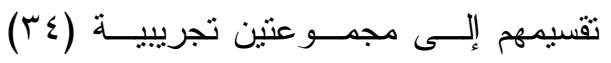

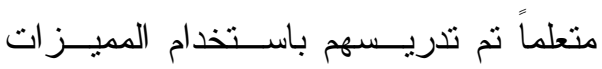

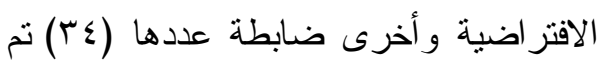
تدريسهم بالمختبر التقليدي • و استخدم الباحث

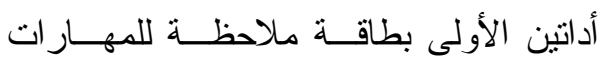

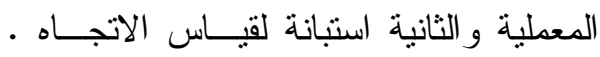

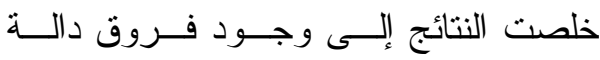
إحصائيا عند بين منوسط درجات اكتسساب

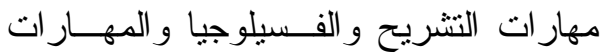

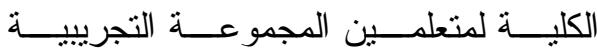
و المجمو عة الضابطة وعدم وجود فروق بين

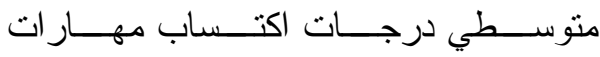

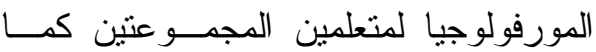
خلصت الدراسة إلى وجــود فــروق دالـــة إحصائيا بين المتوسطات الحسابية لــدرجات

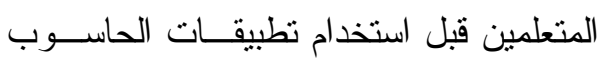

جميع محاور الدراسة لــــالح المتعلمـين ذوي

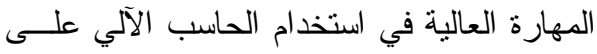
زملائهم ذوي المهارة الضعيفة (ما عدا محسور الفي

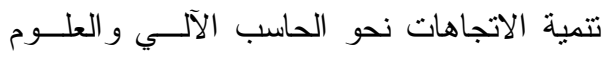
بالنسبة للمعلمين).

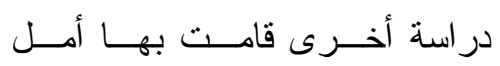

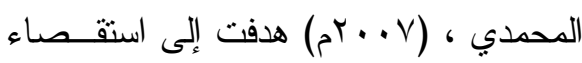
فاعلية المعمل الافتراضـــي فــي تحـــيل المستويات المختلفة لمتعلمات الصف الثـاني لئي الثانوي في مقرر الكيمياء محاولـــة إيجــاد حلول عملية لعدة مشاكل نربوية كــان مــن مئن أهمها مشكلة التز ايد الطلابي الحاد ومــشكلة لتشنة النقص و العجز في المختبر ات الدر اسية مــن

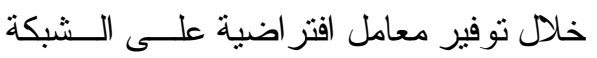
العالمية ، كما هدفت تلك الدر اسة الى معرفة

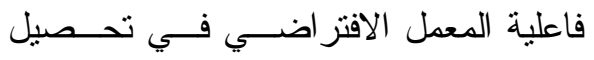

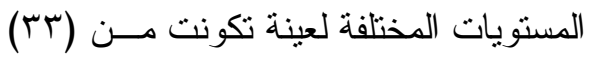

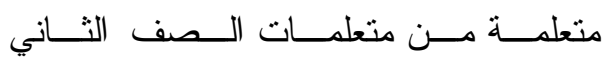

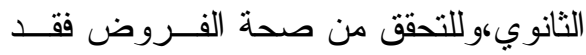
استخدمت الباحثة المنهج شبه التجريبي حيث قسمت العينة إلى مجمو عنين مجمو عة ضابطة تكونت من (7 (1) متعلمة درست باســتخدام المعمل التقليدي ومجمو عة تجرييية تكونت من متعلمة درســت باســتخد ام المعهـل (IV) الافتر اضي .و أسفرت نتائج الدر اســـة عــن فئن وجود فروق ذات دلالة إحصائية بين درجات

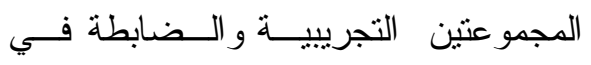


نظره طبقا لموقعه في الفـــاء الافتر اضــي الجزء الثالث و هو (interface) و الذي يقدم

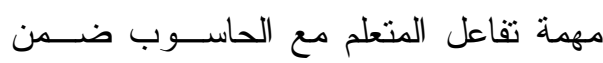
المحتبر وتحول أعمال المتعلم إلى بيانات في المكون المنطقي ، وكل جزء مــن المختبـــر

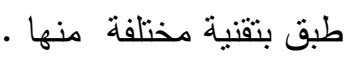
وحول تحــسين مخرجــات الــتعلم

بمساعدة الحاسوب كانــت دراســة تـششانج

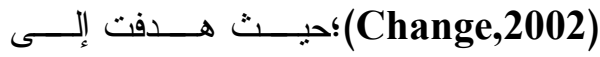

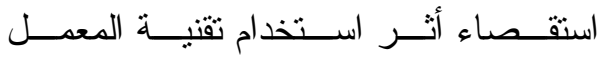
الافتز اضي المبني علـى حـلـ المــشكلات بالحاسوب ومقارنتها مع طريقــة التـدريس

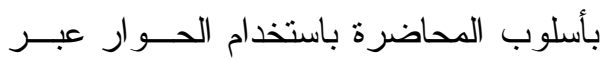
الإنترنت لدى متعلمين المرحلة الثانوية فــي

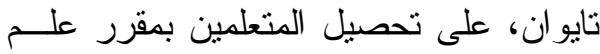

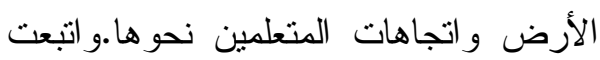
الدراسة المنهج التجريبي القائم على استخدام

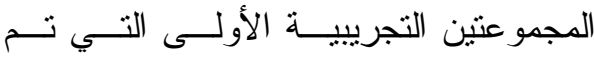

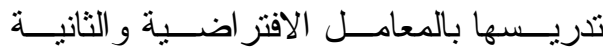

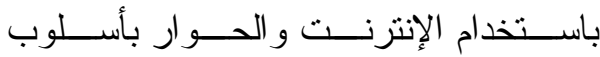

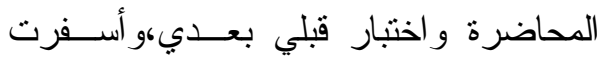
نتائج الدراسة وجود فرق ذي دلالة إحصائية

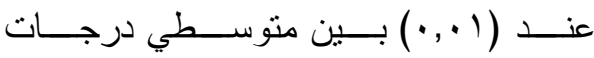
المجموعنين التجريية الأولى والثانية لصالح المجموعة التجريبية الأولى التي استخدمت المعمل الافتز اضي في الاتجاهات نحو مقرر

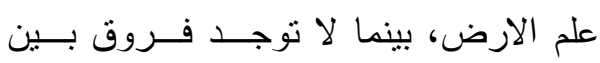

و المختبر ات الافتراضية وبعـــ الاســتخدام

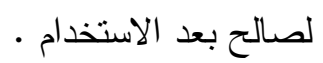
أما في مجال الفيزياء فكانت دراسة أفــردنيس(Avradinis \& et.al ,2001) ،التي هدفت إلى اســتخدام تقنيــات الواقــع الافتر اضي لهحاكاة تجارب الفيزياء حيث قام الباحثون بتطوير الوسائط المتعددة الكلاسيكية

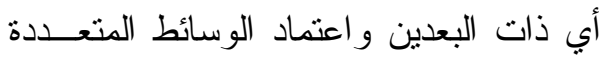

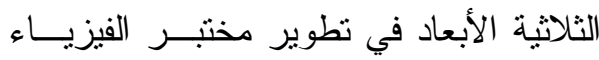
الافتر اضي لإنتاج مستوى عال من التفاعـلــل

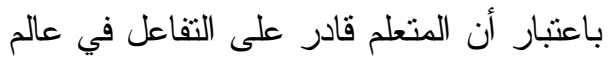

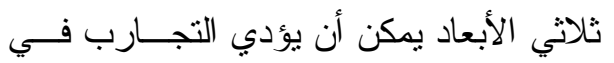
الوقت الحققي ،و اتبعــت الدر اســة المــنهج الوثائقي القائم على أسلوب الجمع و التحليـلـل من خلال الرجوع للأدبيات و التزاث العلمي ولي

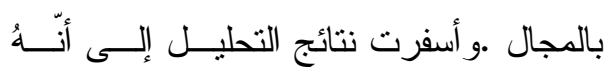

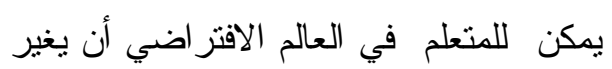

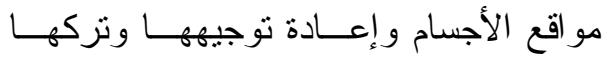

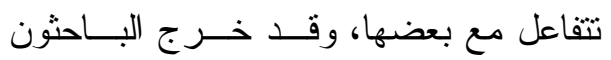

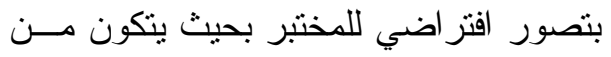

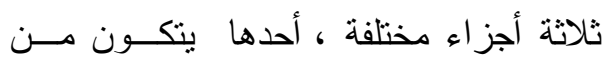

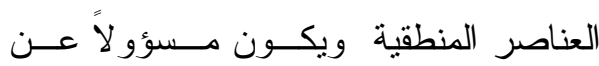
العروض المستتدة الى المحاكــاة بتطبيــق

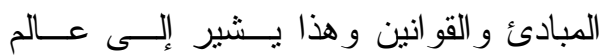

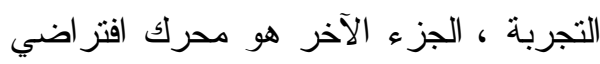

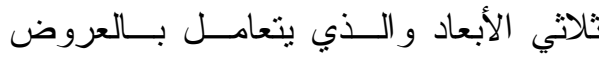
البصرية للمختبر ويجعل المتعلم يكون وجهة 
بالقياس القبلي ، وتنين قدرة المادة التعليميــة

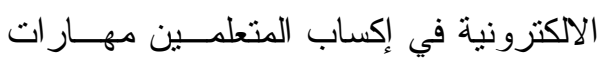

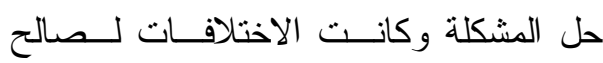

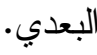

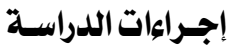

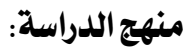

تحددت منهجية البحث فـي ضــوء الهدف الذي يسعى الباحــث إلــى تحقيقــه،

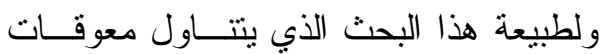

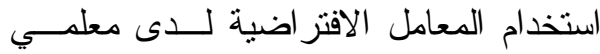

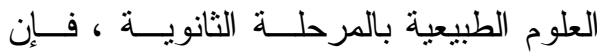

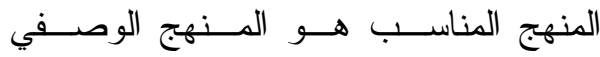

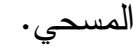

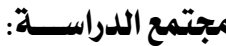

تكون مجتمع البحث من جميع معلمي

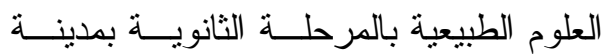
الطائف للفــصل الدراســي الثــاني للعــام

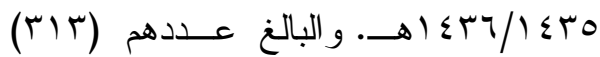

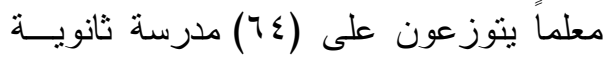

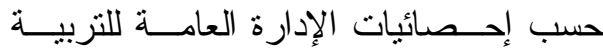

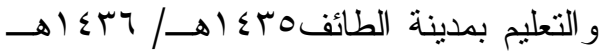
موزعين على المنــاطق الجغر افيـــة وفقِــا لمكاتب التزبية و التعليم كما نبين النتائج فــي

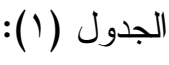

متوسطي الطريقتين علــى نتــائج القيــاس البعدي للاختبار التحصيلي بالرغم من وجود لهني فروق ظاهرية لصالح التجريبية الأولى.

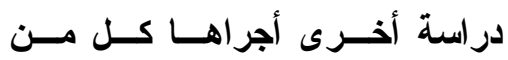

Dimitrov, McGee ( دمتروف وهوارد \& Howard, 2002 ، هدفت إلى اكتثاف التغير في قدر ات المتعلمين العلميــة لاتقــان مهار ات العلوم باستخدام بيئة التعلم القائمــة على الوسائط التعليمية الالكترونية. وتكونت

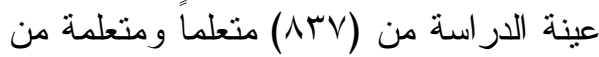
متعلمين المرحلة الإعداديــة مدـن درســوا

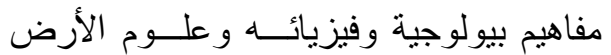
و الفضاء من خلال مشروع قريــة الفـضاء الافتراضي القائم على الوســائط التعليميــة الالكترونية و التي اثتملت موضو عات فلكية و النظام الثمسي، حيث تم وضع هذه القرية الفضائية في مركز جامعة ويلنج اليـسوعية لتقنيات التعليم بتمويل مــن مؤسـسـة العلــم الوطني لتساعد المتعلمين على تعلم المفــاهيم

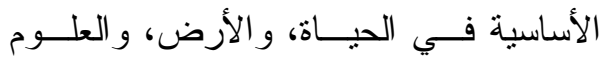
الطبيعية. علم الفلك وبالمقارنة مع الطريقــة التقليدية في تدريس العلوم ،اتبعت الدراســـة

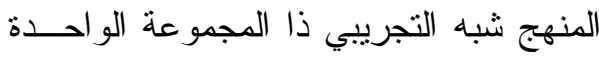

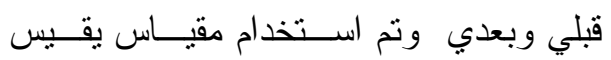

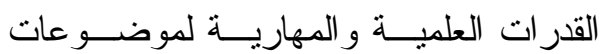
الوحدة التعليمية ،و أظهرت نتـائج الدراســـة فئة

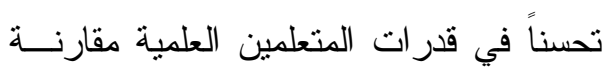


جدول ( ) ) توزيع أفراد مجتمع الدراسة معلمي العلوم الطبيعية بالمرحلة الثانوية وفقاً لمكاتب التربية والتعليم

\begin{tabular}{|c|c|c|c|c|c|c|c|c|}
\hline \multicolumn{2}{|c|}{ المجموع الكلي } & \multicolumn{2}{|c|}{ مكتب الحويـة } & \multicolumn{2}{|c|}{ مكتب الغزب } & \multicolumn{2}{|c|}{ مكتب الشرق } & \multirow{2}{*}{ مكاتب التربية والتعليم } \\
\hline$\%$ & ك & $\%$ & ك5 & $\%$ & ك5 & $\%$ & ك & \\
\hline$\%$ \% & $\wedge \vee$ & $\%$ \% & M & $\%$ \% & r) & $\% r v$ & ro & الكيمياء \\
\hline$\% r \varepsilon$ & $V Y$ & \%rr & $r \varepsilon$ & $\% \nvdash \leq$ & 11 & $\%$ \% & $r \varepsilon$ & الفيزياء \\
\hline$\% \leq r$ & 1Tו & $\% \varepsilon 1$ & $\varepsilon \varepsilon$ & $\% \leq 7$ & ro & $\% \varepsilon$. & or & الأحياء \\
\hline$\% 7$ & 19 & $\% \vee$ & $\wedge$ & $\% r$ & r & $\% v$ & 9 & علم الارض \\
\hline$\% 1 \ldots$ & سו & $\% 1$. & $1 \cdot v$ & $\% 1 \ldots$ & $\mathrm{VI}$ & $\% 1 \ldots$ & $\mu$. & المجموع الكلي \\
\hline
\end{tabular}

المصدر:(الإدارة العامة للتربية والتعليم للبحث و التي كانت: التخـصص، وسـنوات

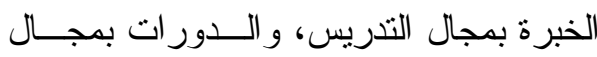

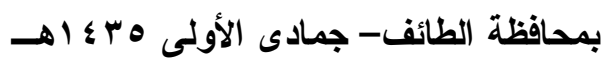

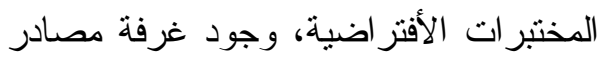
مستقلة بالمدرسة،حيث تم حساب التكرارات

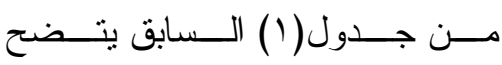

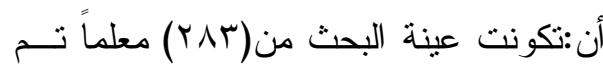
و النسب المئوية لعينة الدراسة مــن معلمــي لئسي

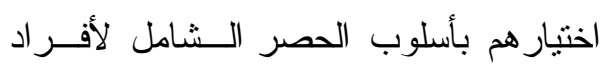

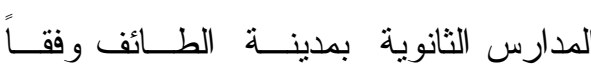

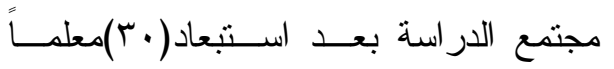
لتطبيق الإستبانة عليهم كعينــة اســنطلاعية لمتغير اتها.

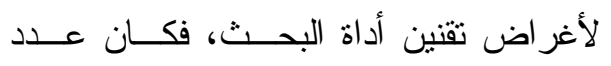

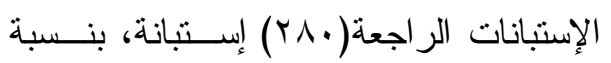

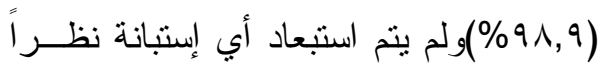

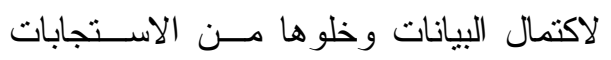

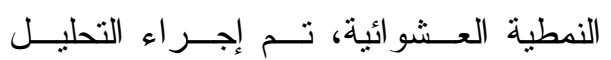

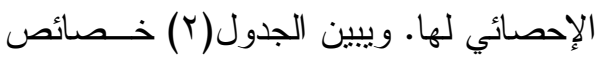
أفراد العينة وفقًا للمتغيرات و البين لجيانات الأولية 


\section{جدول (ץ )}

خصائص أفراد مجتمع الاراسة بحسب المتغيرات الأولية

\begin{tabular}{|c|c|c|c|}
\hline النسبة المئوية & العدد & مستويات المتغير & المتغير ات \\
\hline \%чт, \& & $V \varepsilon$ & الفيزياء & \multirow{4}{*}{ التخصص } \\
\hline$\%$ YV,1 & VI & الكيمباء & \\
\hline$\% \leqslant r, 0$ & 119 & الأحياء & \\
\hline$\% r, q$ & 11 & علم الأرض & \\
\hline$\% r r, q$ & $7 \varepsilon$ & أقل من 0 سنوات & \multirow{3}{*}{ سنو ات الخبرة التدريسية } \\
\hline$\%$ \%०, ₹ & V) & من م إلى أقل من • اسنو ات & \\
\hline$\% 01, \wedge$ & $1 \leq 0$ & من • ا سنو ات فأكثر & \\
\hline$\%$ \%↔, 9 & 1.9 & لا نوجد دور ات & \multirow{4}{*}{ الدور ات بمجال المختبر ات } \\
\hline$\%$ \%r, 9 & TV & من دورة إلى دورتين & \\
\hline$\%$ \%r, & 77 & من ثلات إلى أربع دور ات & \\
\hline$\% \backslash r, 7$ & $r \Lambda$ & من خمس دور ات فأكثر & \\
\hline$\% \wedge r, q$ & rto & نعم & \multirow{2}{*}{ لغل يوجة مكان مخصص المصادر التعليمية لتنفيذ التقل } \\
\hline$\% \backslash 7,1$ & $\varepsilon 0$ & y & \\
\hline
\end{tabular}

يتضح من الجدول رقم(Y) أن بعض أن بعض المعلمين لم يشاركو ا في دورات تدريبية بمجال المختبرات الافتر اضية بنسبة لونية (\%r^, q)

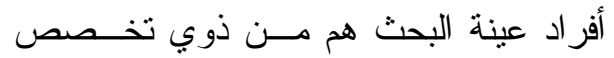
التحقو ا بدورة إلى دورتين ، بينما بلغت نسبة لهن

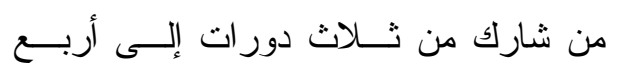

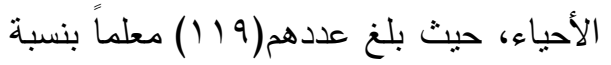

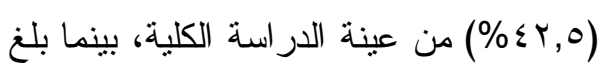

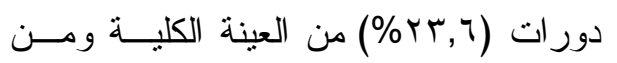

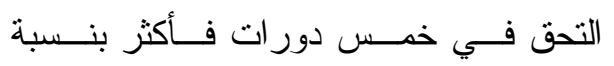
. $(\%, r, 7)$ تتائج البحث والتوصيات والمقترحات: فيما يلي يتم عرض للنتائج التي أسفر

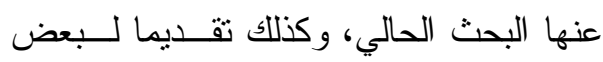

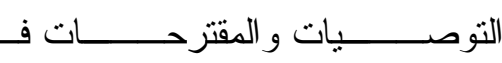

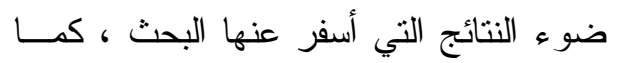
يلي:

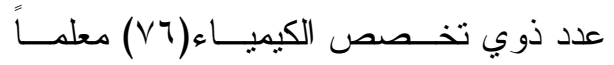

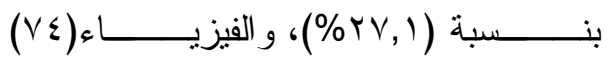

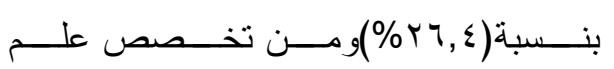

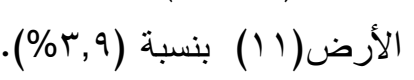
و أن بعض المعلمين تتزاوح خبراتهم

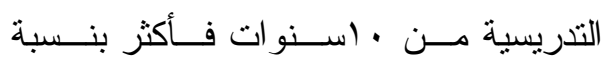

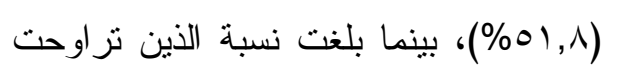

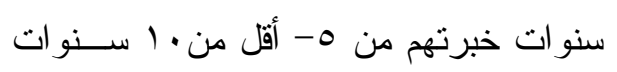

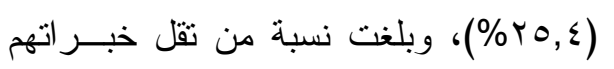

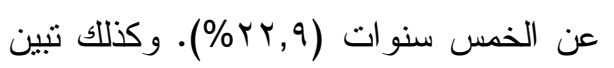


المدرسية نقص وجود أجهزة حاسـبـ

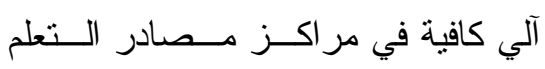
بالمدرسة " و افتقار وجود فني لتـشغيل فرديل أجهزة مصادر التعلم أو المعمل للصبانة " بينما جاء بعض المعوقات في الرتب

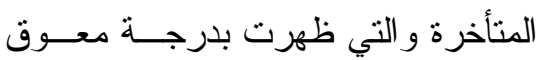
كبير مثل" ضعف البرمجيات الموجــودة

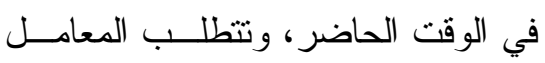

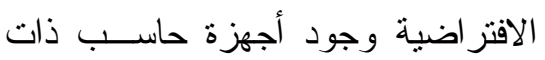

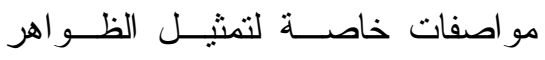
المعقدة بشكل و اضحح ، ومحدودية عـدـد المتخصصين في هذا النوع من المعامل ومن وديه الافتر اضية.

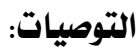

في ضوء نتائج البحــث يثمنــــ التوصــية بالآتي : ا ـ العمل على توفير برمجيــات وبـــرامج

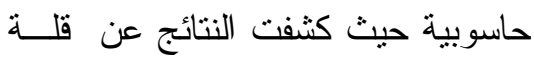
نو افر بر امج للمعامل الافتر اضية تتاسب

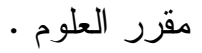

r. العمل على توفير شبكة الإنترنت بشكل

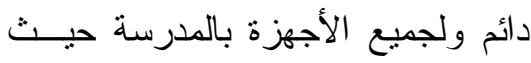

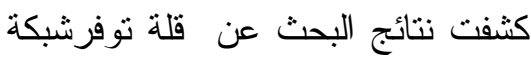

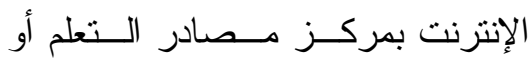
المعامل الافتز اضية بدرحة كبيرة. r. العمل على تدريب معلمي المــدارس الثانويــة علــى اســتخدام المعامـلـل

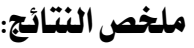

يمكن ذكر أهم النتائج التي توصل إليه البحث في الآتي :

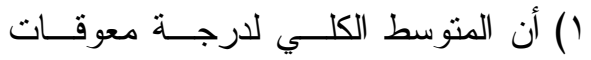
استخدام المعامل الافتز اضية لدى معلمي لاني لوني العلوم الطبيعية في المـــارس الثانويـــة بدرجة أثر كبير ،جاء المعـوق المتعلــق

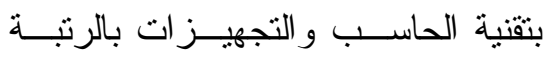
الأولى وبدرجة كبيرة ، ثــم المعـوق المتعلق بمقرر ات العلوم بدرجة كبيرة أبرز المعوق الذي كثف عنها البحث

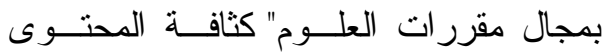

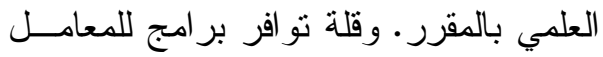

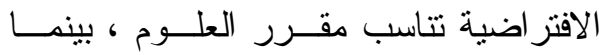
جاءت العبارتنان " قلة مناسبة الموضـــوعات المتــضمنة فــي محتــوى مقــرر العلــوم لاستخدامها في هذا النوع مــن الممارســات

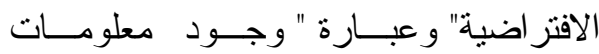
إضافية بالمقرر تحول دون الاسـتفادة مــن استخدام المعامـلـل الافتر اضــية " بــالرتبتين الأخيرتين بدرجة أنز كبير

r جاءت عبارة و احدة بالرتبـــة الأخيــرة

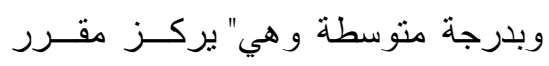

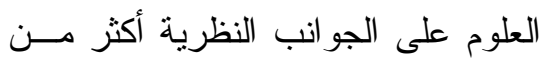

$$
\text { الجانب العملي. }
$$

r) أبرز المعوق الذي كثف عنها البحــث

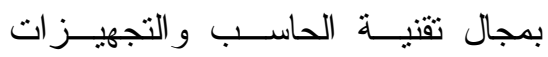


الأساسي بغزة، رسالة ماجستير غيــر

$$
\text { منشورة، الجامعة الإسلامية، غزة. }
$$

ع. أحمد، زاهر (99v (م) تكنولوجيا التعليم

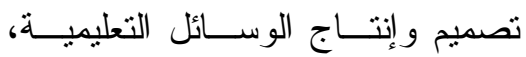

المكتبة الأكاديمية، القاهرة، مصر.

ه. الأحمدي، أميمه بنت حميــد مبــارك

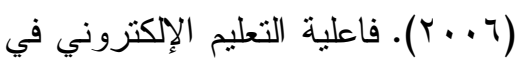

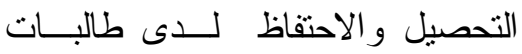

العلوم الاجتماعية بكلية الآداب و العلوم

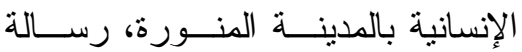

ماجستير غير منشورة، جامعة طيبـة،

المدينة المنــورة، المملكـــة العربيـــة

السعودية.

T. الأحمدي، محمد بن حسسين (0. . ب).

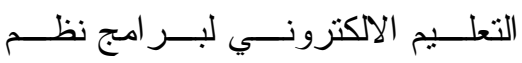

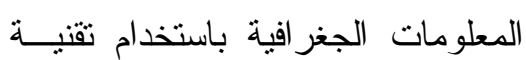

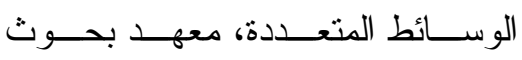

الفضاء، مدينة الملك عبد العزيز للعلوم و التقنية، الرياض.

V. آل أحمد، عبدالعزيز عبـود (r...

و اقع موضوعات التجارب المعملية في

مقرر الأحياء للصف الثالث الثـانوي

بالمملكة العربية الـسعودية وبعـض اهض

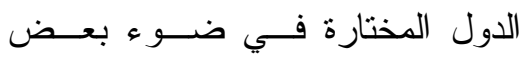

الممارسات الو اقعية. رسالة ماجسستير

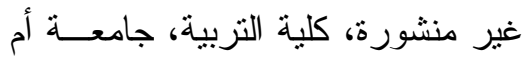

القرى، مكة المكرمة.
الافتر اضية في تدريسهم للجانب العملي

بمقررات العلوم حيث كـشفت نتــائج الدراسة عن معوق التدريب.

ع. ضرورة العمل على تخفيــف الأعبــاء

الموكل بها معلمــو العلــوم الطبيعيـــة

بالجو انب الفنية و الإداريـــة لتفــريغهم

لإعداد وتحضير التجارب الافتر اضية

هـ العمل على تــوفر أجهـزة الحاســوب

وربطها بالثبكة الداخلية للمدرسة بمكان

مستقل عن معمل الحاسب بالمدرسة.

\section{المراجع - الماجع}

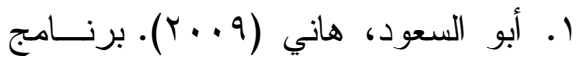

تقني قائم على أسلوب المحاكاة لتتميـــة

بعض مهار ات ما ور اء المعرفة فـي

منهاج العلوم لدى طلبة الصف التاسع

الأساسي بغزة، رسالة ماجستير غيــر

منشورة، الجامعة الإسلامية، غزة.

r. أبو خطوة، السيد عبد المــولى الـسيد

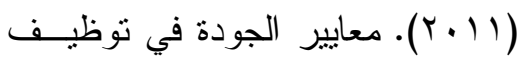

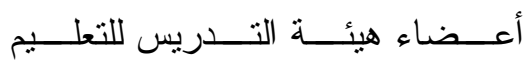

الإلكتروني، بحث مقدم إلى: المــؤتمر

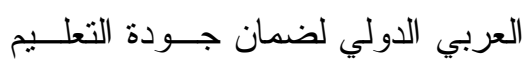

العالي، جامعة الزرقاء، الأردن.

r. أبو ماضي، سـاجدة (11) (1). أثــر

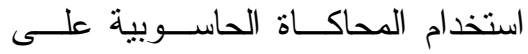

اكتساب المفاهيم و المهار ات الكهربيـــة

بالتكنولوجيا لدى طلبة الصف التاســع 
المعامل الافتر اضية وبعض مطالبهــا

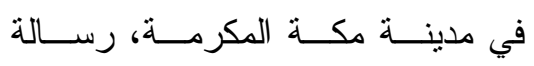
ماجستير غير منـشورة ، جامعـــة ام القرى.

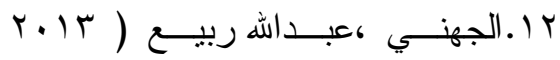
)،معوقات استخدام المعامل الافتر اضية الهية

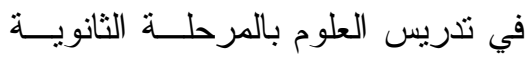

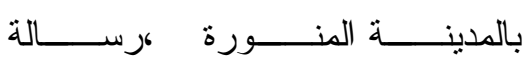
ماجستنير غيرمنشورة ،كليــة التزبيـــة ،جامعة طيبة. المدينة المنورة.

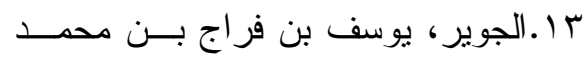

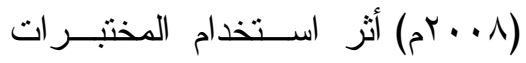

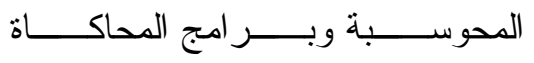

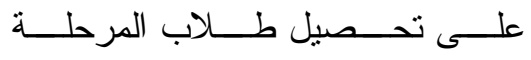
الثانوية واتجاهاتهم نحو مادة الكيمياء،

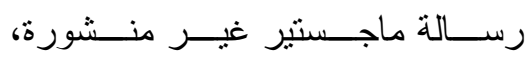

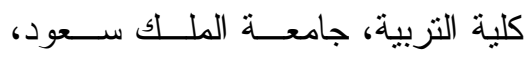
الرياض

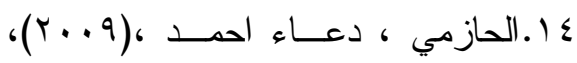
استخدام المعمل الافتر اضي في تدريس وحدة من مقرر الفيزياء في تحـصيل طالبات الصف الثاني الثانوي ، رسالة ماجستير غيــر منــشورة، جامعسـة ام

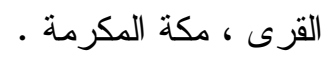

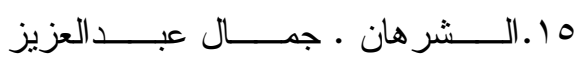

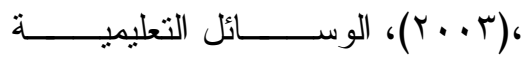
ومستجدات تكنولوجيا التعليم ،المملكـــة المبـة
آل محيا، عبد الله ين يحيى حسن (2008).

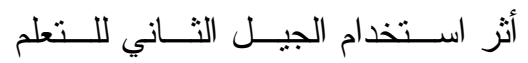

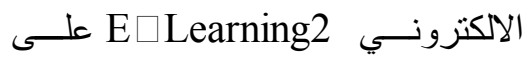
مهار ات التعليم التعاوني لدى طـــلاب

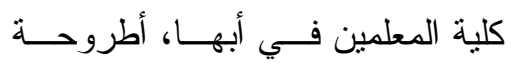

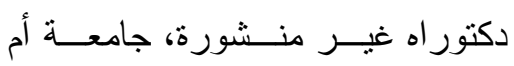
القرى، المملكة العربية السعودية.

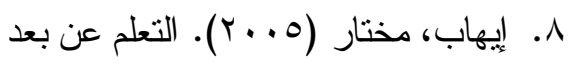
وتحدياته للتعلم الإلكترونــي و أمنـــه.

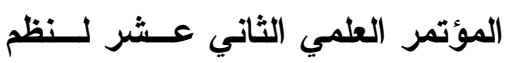
المعلومات وتكنولوجيــا الحاسـبـات،

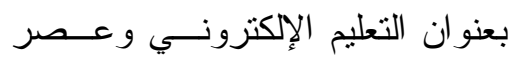

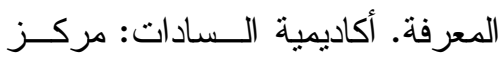

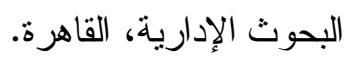

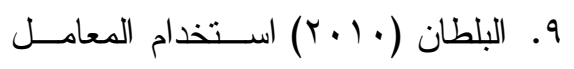
الافتز اضية في تدريس العلوم بالمرحلة

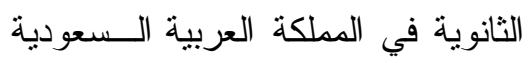

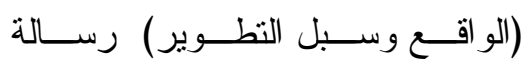
ماجستير غير منـشورة ، جامعــة ام القرى. • ( البياتي ، مهند محمد (T + . rم): الأبعاد العمليـــة و التطبيقيـــة فــــي التعلـــيم

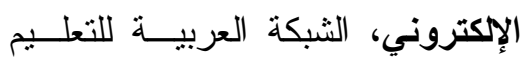

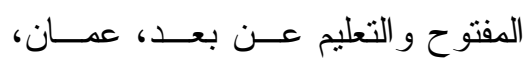
الأردن.

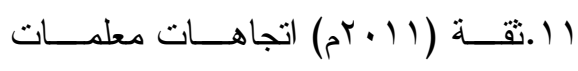
ومشرفات الكيمياء نحو استخدام تقنيــة 


$$
\begin{aligned}
& \text { و الطموح. در اسة ميدانيــة، المــؤتمر } \\
& \text { العلمي الثامن عشر، منـــاهج التعلــيم }
\end{aligned}
$$

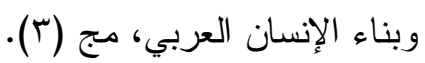

$$
\begin{aligned}
& \text { ا.Y.صـــبري،ماهر وتوفيــق، صــــلاح }
\end{aligned}
$$

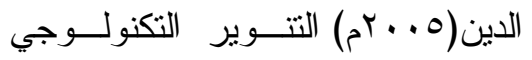

$$
\begin{aligned}
& \text { وتحديث التعليم، الاسكندرية: المكتب } \\
& \text { الجامعي الحديث. } \\
& \text { r.M.صحيفة الشرق المطبوعة العدد رقـم } \\
& \text { (TVA) } \\
& (r \cdot) r-14
\end{aligned}
$$

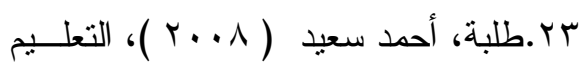

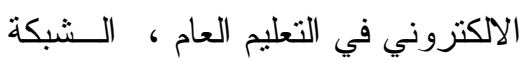$$
\text { العربية للتعليم المفتوح و التعليم عن بعد العديم }
$$$$
\text { ، كمان ، الأردن }
$$

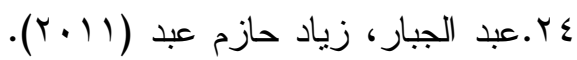$$
\text { التعليم الإلكتروني ومنطلبــات جــودة }
$$

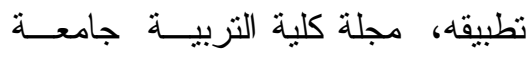

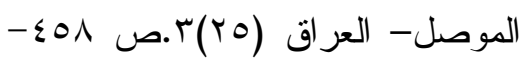$$
\text { .OT }
$$

Or.عبد العاطي، حسن الباتع وأبو خطوة، السيد عبد المــولى الــسيد. (9. . . r). التعليم الإككتروني الرقمي، النظريـــة،

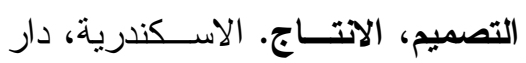

$$
\text { الجامعة الجديدة. }
$$

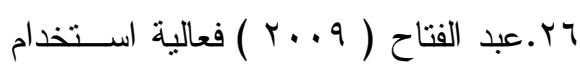
المعمل الافتز اضي في تتمية المهارات
العربية السعودية ، الرياض: مطــابع

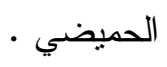

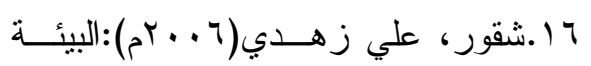

الافتز اضـــية و التعلم،تـــاريخ الزيـــارة 1/10/2014 moufouda.jeeran.com/archive/ 2006/9/94104.html VV .الثناق، قسيم محمد؛ وبنـي دومسي،

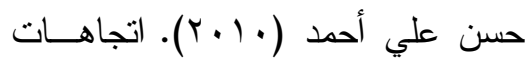
المعلمين و الطلبة نحو استخدام الــتعلم

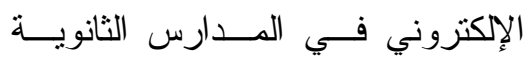
الأردنية، مجلة جامعة دمشق، (Y+1)

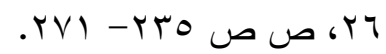
1 1 ـالثهر اني، عامر عبدالله و السعيد، سعيد

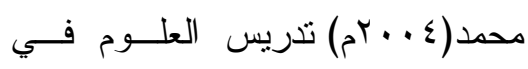

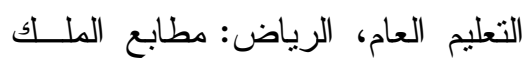
سعود.

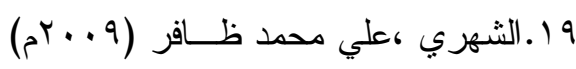

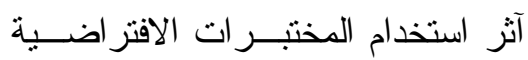

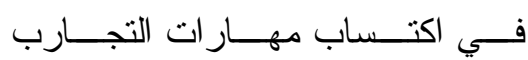

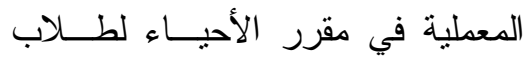
الصف الثالث الثانوي بمدينــة جـــة فئة رسالة دكتور اه غير منشورة ، جامعة أم القرى

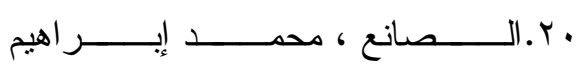

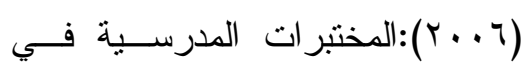

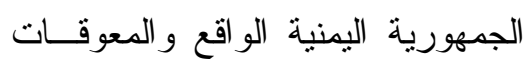


الثانوية بمحافظة المخـــو اة التعليميــة،

رسالة ماجستير غير منشورة، جامعــة

أم القرى، المملكة العربية السعودية.

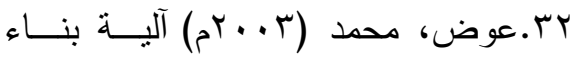

المكتبة الافتز اضبة، مجلــة مـسـتقبل

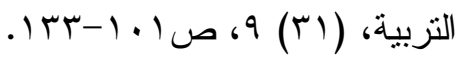

سז. العويد، محمد صالح و الحامد، أحمد بن

عبد الله (ع ع اهــا التعليم الإلكتروني

في كليــة الاتــــالات و المعلومــات

بالرياض : در اسة حالة. ورقة عمـلـ

مقدمة لندوة التعليم المفتوح في مدارس

الملك فيصل، الريـــاض بـــالفترة ب-ه

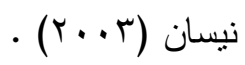

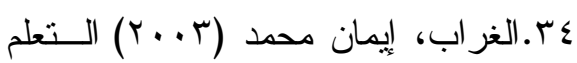

الإلكتروني: مدخل إلى التدريب غيـر

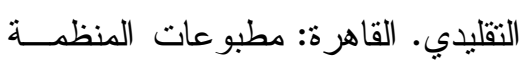
العربية للتتمية الإدارية.

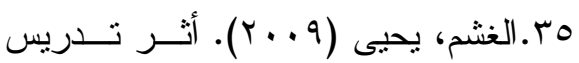
القيزياء بطريقتـي العــرض العملــي المباشر بالمحاكــاة الحاســوبية فــي تحصيل طلاب المرحلة الثانوية، رسالة ماجستير غير منشورة، جامعة صنعاء، صنعاء، اليمن.

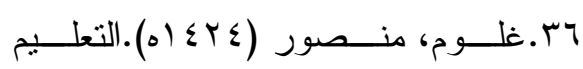

الالكتروني في مدارس وزارة التربيــة -الكويت. الندوة العالمية الأولى للتعليم
العملية للكيمباء لطلاب كلية التربيــة ،

مجلة التزبية العلميـــة ، المجلــــ (Y) (Y)

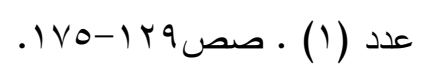

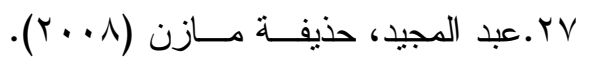

تظوير وتقييم نظام التعليم الاككترونــي

التفاعلي للمـــو اد الدر اســية الهندســية

و الحاسوبية، رسالة ماجـستير غيــر

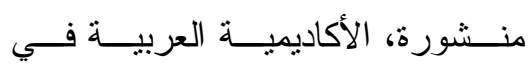

الانمارك.

^r . عبيدات، ذوقان و عدس، عبـــدالرحمن

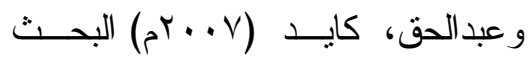

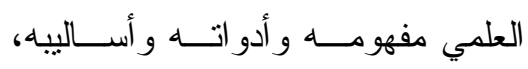

عمان: دار الفكــر للطباعـــة و النــشر

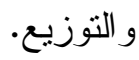

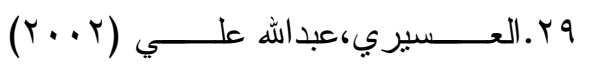

معوقات اســتخدام مختبــرات مـــادة

الأحياء في مدارس المرحلة الثانويـــة

من وجهة نظر المعملين و المــشرفين بالمنطقة الثرقية، رسالة ماجستير غير منشورة، كلية التربية، جامعة الرياض.

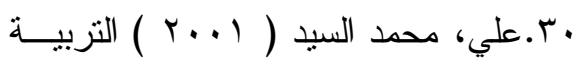
العملية وتدريس العلوم ، القاهرة: دار

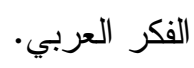

اس.العدري، علـي بـن مسـردد موســى

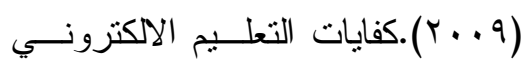

ودرجة تو افر ها لاى معلمي المرحلــة 
41. Awodele, O., Kuyoro, S. O., Adejumobi, A. K., Awe, O. and Makanju, O.(2011). Citadel E-Learning: A New Dimension to Learning System World of Computer Science and Information Technology Journal (WCSIT) Vol. 1, No. 3, 7178, 201171.

42. Balmush.N; Dumbravianu.R. (2005): Virtual laboratory in optics . Third International Conference on Multimedia and Information \&

\section{Communication}

Technologies in Education june 7-10th,200

43. Cengiz TÜYSÜZ (2010)The Effect of the Virtual Laboratory on Students' Achievement and Attitude in Chemistry , International Online Journal of Educational Sciences, 2010,2 (1), 37-53

44. Chang, GwangChol.(2006).Application of Computer Simulation in Education Development
الإكتروني التي عقدتها مدارس الملـــك فيصل بالرياض. مُّاح على الــر ابط: http://www.Kfs.sch.sa/ar/sim.ht

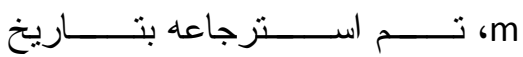
.0) $\leqslant r \leqslant / / T / 0$

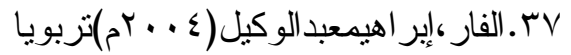
ت الحاسوب وتحديات مطلــع القــرن الحادي و العشرين، القاهرة: دار الفكر

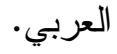

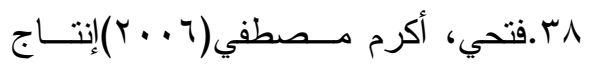
مواقع الانترنت التعليمية رؤية ونماذج تعليمية معاصرة في التعلم عبر مواقع الانترنت، القاهرة ، عالم الكتب.

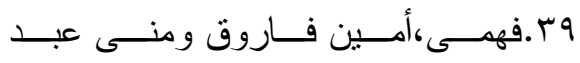

الصبور (1 + . r):المنحى المنظومي في في مواجهة التحديات التربوية المعاصــرة و المستقبلية. القاهرة:دار المعارف.

40. Avradinis ,Nikos,\& Spyros VosinakisThemis Panayiotopoulos (2001): Using Virtual Reality Techniques for the Simulation of Physics Experiments Dept. of Informatics, University of Piraeus, Knowledge Engineering Laboratory, 80 Karaoli \& Dimitriou Str, 18534 Piraeus, Greece. 
Case Exploratory Learning of

Diffraction Grating," etcs, vol.

3, 2009 First International

Workshop on Education

Technology and Computer

Science

49. Ferguson, C.(2008). Historical

Introduction to the

Development of Material

Science and Engineering as

a Teaching Discipline, higher

education center

50. Hadjerrouit, S. (2010).

Developing Web-Based

Learning Resources in School

Education: A User-Centered

Approach Interdisciplinary

Journal of E-Learning and

Learning Objects 1 (6),

P101-133

51. Jensen, N.; Voigt, G.; Nejdl,

W. \& Olbrich, S. (2004)

"Development of a Virtual

Laboratory System for

Science Education"

Interactive Multimedia

Electronic Journal of

Computer-Enhanced

Learning :

http://imej.wfu.edu/articles/
Planning, Education Sector

UNESCO.

45. Change. (2002): Does

Computer-Assisted

Instruction Problem Solving = Improved Science Outcomes?

A pioneer Study. Journal of

Education Research, 95(3), 143-150.

46. Curran, C. (2004). Strategies

For E-Learning In

Universities Research And

Occasional Paper Series:

Cshe.7.04 University Of

California, Berkeley.

September 2004.

47. Dimitrov, D. M., McGee, S., \& Howard, B. C. (2002). Changes in students' science ability produced by multimedia learning environments: Application of the linear logistic model for change. School Science and Mathematics Journal, 102(1), 15-22.

48. Ding ,Yimin\& Hao Fang,(2009): "Using a Simulation Laboratory to Improve Physics Learning: A 


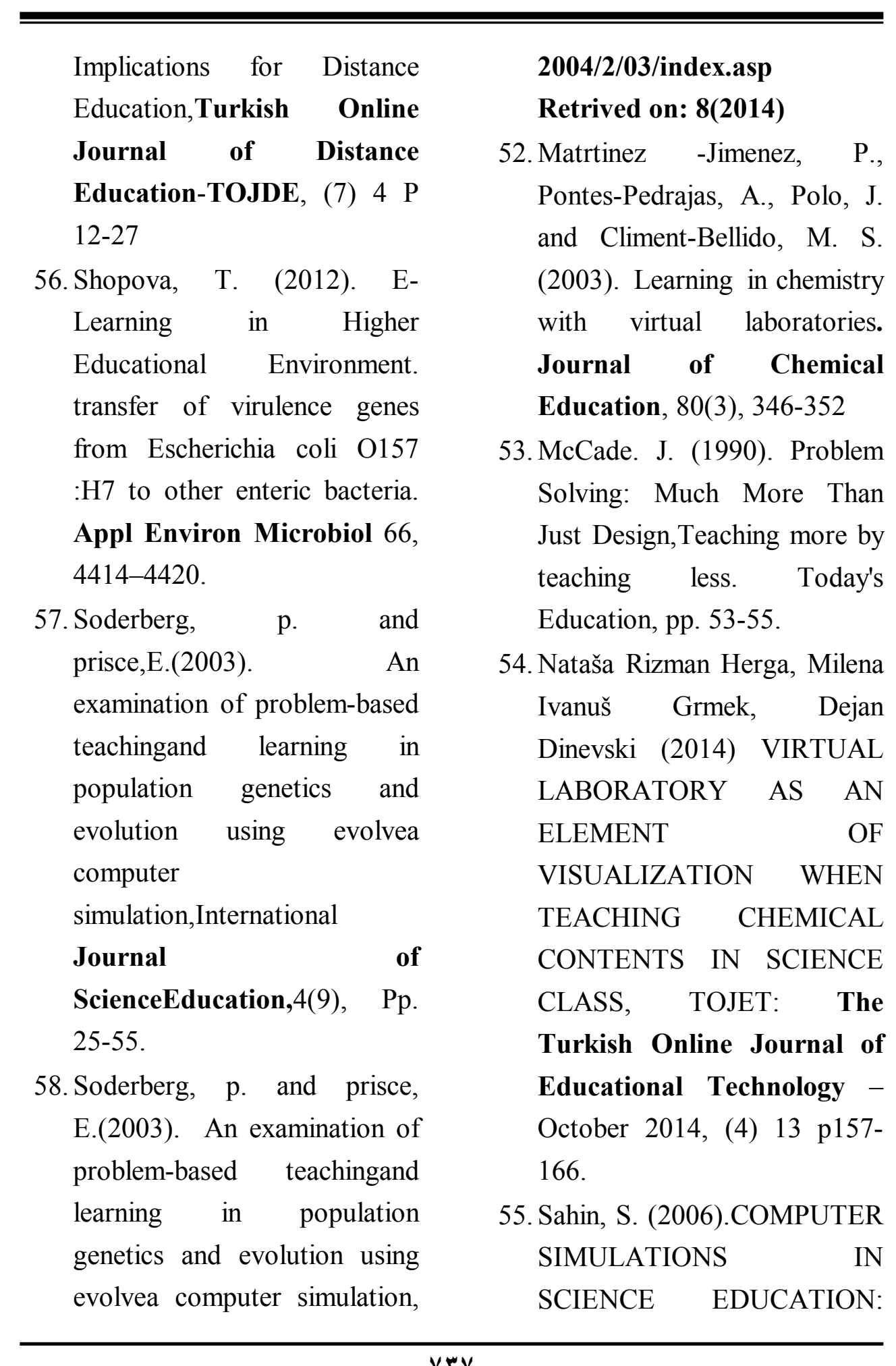


61. Yaron S, Kolling GL, Simon

L, Matthews KR (2000)

Vesicle-mediated transfer of virulence genes from Escherichia coli $\mathrm{O} 157: \mathrm{H} 7$ to other enteric bacteria. Appl Environ Microbiol 66:44144420

62.Zhu,S., Xie, F.and Levinson, D.(2011).Enhancing

Transportation Education through Online Simulation Using an Agent-Based Demand and Assignment Model,Journal Of

Professional.Issues in

Engineering Education and

Practice.1(2) P120-128
International Journal of

ScienceEducation,4(9), $\mathrm{Pp}$. 25-55.

59. Tlaczala, W. M. Zaremba, A. Zagorski and G. Gorghiu (2006): Virtual physics laboratory for distance learning developed in the frame of the VccSSe European project, This work was funded through the Socrates-Comenius

2.1 .

European project 128989CP-1-2006-1- ROCOMENIUS-C21: "VccSSe 60. Woodfield, B.F.; Catlin, H.; Waddoups, G.; Moore, M.; Swan, R ؛.Allen, R.; Bodily, G. (2004). The virtual chemLab Project: A Realistic and Sophisticated Simulation of Inorganic Qualitative Analysis Journal of Chemical Education, 81, (11), 1671-1678. 